\title{
GUGAT CERAI: MEMBEBASKAN PREMPUAN DARI PENDERITAAN?
}

\author{
Nurmala Fahriyanti ${ }^{1}$
}

\begin{abstract}
In Mataram West Nusa Tenggara, people is lives are regulated on daily basis by religious law, traditional (adat) law and state law. To understand these complex cultural and religious processes as they affect women in particular, I will examine the issue of divorce, also known as sue divorce. This tipe of divorce is socially-sanctioned. I will focus my examination in Mataram, an city of Lombok West Nusa Tenggara. In Lombok society marriage constitutes an important part of the life cycle. Someone is not considered an adult until marriage. Marriage is not only united two individual, but also united two families. However this dream canot be realized over the long term. If family problems arise and there are no suitable solutions, people may choose to divorce. For instance, if a wife unable to fulfill her obligations as a wife, her husband can divorce her by verbal means alone, according to any of the three existing legal systems (religious customary or state law). By contrast, if her husband unable to fulfill her obligations as a husband his wife can divorce him in only one way by making an application to Islamic Court to do divorce.
\end{abstract}

\section{Keyword: Gugat Cerai, Syiqaq, Resolusi, Damai}

\section{PENDAHULUAN}

Perkawinan merupakan wadah yang mempunyai makna dan akibat yang cukup luas, maka setiap insan yang hendak melaksanakan perkawinan harus memahami dan melakukannya dengan cara dan prosedur yang benar menurut hukum Islam dan Undang-Undang No. 1 tahun 1974 tentang Perkawinan dan peraturan-peraturan yang berlaku untuk hal tersebut. ${ }^{2}$ Perkawinan adalah ikatan lahir batin antara seorang pria dan seorang wanita sebagai suami istri dengan tujuan membentuk keluarga (rumah tangga) yang bahagia dan kekal berdasarkan Ketuhanan Yang Maha Esa. ${ }^{3}$ Untuk merealisasikan tujuan tersebut, rumah tangga sebagai unit terkecil dalam masyarakat memegang peranan penting dalam menyiapkan sumber daya manusia yang handal dan mampu berkompetensi baik di tingkat lokal maupun tingkat Internasional. Kesejahteraan rumah tangga merupakan masalah yang cukup kompleks terlebih pada era globalisasi dan informasi yang serba cepat seperti sekarang ini. Oleh karena itu, seyogyanya disadari bahwa perkawinan adalah peristiwa besar, karena segala sesuatu yang terjadi di dalamnya akan sangat mempengaruhi segala sesuatu yang terjadi dikemudian hari. Suatu perkawinan akan menimbulkan beberapa sebab dan akibat yang terjadi pada

1 Penulis adalah peminat kajian hukum Islam. Memproleh Magister di bidang Hukum Islam konsentrasi Akhwalusyahsyiah UIN Mataram, sehari hari adalah Dosen tetap STEI Hamzar Lotim dan presenter tetap TVRI NTB. Email: nurmala_fahriyanti@yahoo.com

2 Depag RI, Bahan Penyuluhan Hukum, Undang-undang Perkawinan No.1 tahun 1974. Tentang Perkawinan, 117.

3 Sobri Mersi Al-Faqi, Solusi Problematika Modern, (Surabaya: Pustaka Yasir, 2011), 29. 


\section{Qawwãm • Volume 13 Nomor 2, Desember 2019}

masing-masing individu maupun pada masyarakat luas. Maka dalam melaksanakan perkawinan hendaknya berhati-hati dan penuh pertimbangan agar tercapai tujuan perkawinan itu sendiri. 4

Tujuan perkawinan itu sangat mulia, maka seharusnya perkawinan tersebut dilaksanakan sesuai dengan ketentuan ajaran agama dan peraturan perundangundangan yang berlaku. Akan tetapi dalam kenyataannya, masih banyak yang tidak mematuhi undang-undang tersebut, sehingga tidak dapat dipungkiri bahwa seringkali terjadi permasalahan serius dalam suatu perkawinan. Dalam perkawinan terdapat pasangan yang berhasil membangun dan membina keluarga yang sakinah, mawaddah dan warahmah. ${ }^{5}$ Akan tetapi, tidak jarang juga yang tidak berhasil dan berakhir dengan perceraian. Perceraian merupakan suatu hal yang sering terjadi dalam kehidupan pasangan suami istri baik cerai talak maupun cerai gugat, oleh karena itu hukum Islam menaruh perhatian yang cukup signifikan terhadap hal tersebut. Hal ini dapat terlihat apabila mengkaji hukum Islam, niscaya akan temukan kedua hal tersebut serta hukumnya menurut hukum Islam. Perceraian berlangsung karena adanya perkawinan, tidak ada perceraian tanpa diawali perkawinan. Namun pada saat tujuan itu tidak tercapai, maka perceraian merupakan jalan keluar (way out) terakhir yang mesti ditempuh. Perceraian tidak dapat dilakukan kecuali dengan alasan-alasan yang dibenarkan oleh syara' dan undang-undang. Dalam hukum Islam, alasan-alasan perceraian itu mengalami perkembangan sesuai dengan seting sosial yang melingkupi hukum. ${ }^{6}$

${ }^{4}$ Al-Qur'an Surat an-Nisa(4) ayat 35

5 Dedi Junaedi, Bimbingan Perkawinan, Membina Keluarga Sakinah Menurut Al-Qur'an dan asSunnah, (Jakarta: Akademi Presindo, 2010), 15.

6 Shoheh Fiqh Sunnah 1. Mubah, its rule is women was hateful cohabit its husband because dislike and fear can't accomplish its husband rights that and can not uphold Allah limitation in obedience to her, with God's decree basic: "Ifyou are worried that both (spouse) can't carry on Allah laws, therefore no sin on both about pay which gave for a wife redeems her." (Qs. Al Baqarah 2:229). Ibnu Hits to give rule with al Khulu' it by declares for that it is a husband divorce its wife with replacings paying hand over to husband. This was prohibitted but in a state worried both or one of it can't perform that commanded by God. It can appearance of to be not deep sukaan family intercourse, can become since its bad behavior or its fleshly thing. And so do lost this prohibition if both needs since worried al Bainunah al's causative sin I bra (big separate or divorce three). Syeikh al Basâm declares for al Khulu lets that' (sue parts) for woman if wives hate its husband behavior or worried sin because can't accomplish its rights. If husbands loves it, therefore for following sunnah wives patient and not chooses separate. 2. Bastard, if husband gets into a mess wives and boycott it or not give its rights witting and a sort it that wives pays to her ransom by way of divorce sue. $\mathrm{Al} \mathrm{Khulu'} \mathrm{the} \mathrm{batil} \mathrm{and} \mathrm{its} \mathrm{ransom} \mathrm{is} \mathrm{backed} \mathrm{to} \mathrm{woman} \mathrm{and} \mathrm{woman} \mathrm{state} \mathrm{makes} \mathrm{a} \mathrm{abode} \mathrm{as}$ origin it, if khulu' not with lafazh divorce. And if wife asks for to part eventually its family relationship good and not happening dispute and wrangle between wife husband couple and no reason syar ' i. one corrects to mark sense khulu '. 3. Sunnah, if husband despises (Mufarrith) right for rights God therefore wives following the sunnah al Khulu' terminological Ahmad Bin Hambal's. 4. Mandatory, sometimes al Khulu' as its law mandatory on plays favorites situation as person that never does sholat, eventually was reminded. Such also on problem, suppose husbands have confidence or conduct who can issue it of islam and makes it heterodox. Women can't prove it infrint of jurisdiction judge for punishment apart or can prove it, but judge jurisdiction not heterodox give the punishment and nor part liabilities. Therefore mandatory to the woman of 


\section{Pengertian Gugat Cerai}

Perceraian merusak hubungan perkawinan dan olehkarenanya selalu menyakitkan. Pada dasarnya hukum Islam menetapkan bahwa alasan perceraian yaitu pertengkaran sudah memuncak dan membahayakan keselamatan jiwa yang disebut dengan "syiqaq" sebagaiman Firman Allah, artinya: Jika pasangan suami istri khawatir terjadinya perselisihan perselisihan tidak hanya berarti pertengkaran antara suami atau istri bisa juga perbedaan prinsip dan pendapat maka utuslah seorang hakam (utusan) dari keluarga suaminya dan seorang hakam (utusan) dari keluarga istri. Dan jika kedua pasangan suami istri menghendaki kebaikan maka Allah akan memberikan petunjuk kepada keduanya. ${ }^{8}$ Gugat cerai atau dalam bahasa Arabnya adalah al-Khulu' ( الخُلْع ). Kata (الخُلْعُع) dengan didhommahkan huruf kho'nya dan

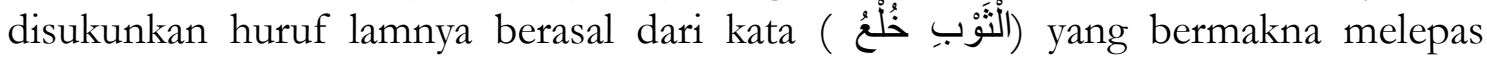
pakaian. Lalu digunakan untuk istilah wanita meminta kepada suaminya untuk melepasnya dari ikatan pernikahan yang dijelaskan Allah sebagai pakaian, yang artinya: "Mereka itu adalah pakaian, dan kamu pun adalah pakaian bagi mereka." (Qs. AlBaqarah 2:187).

Sedangkan dalam pengertian syari'at, para ulama mengungkapkannya dalam banyak definisi yang semuanya kembali kepada pengertian bahwa al-Khulu' adalah terjadinya perpisahan (perceraian) antara sepasang suami istri dengan keridhoan dari keduanya dan dengan bayaran yang diserahkan istri kepada suaminya. ${ }^{9}$ Sedangkan Syeikh al-Basâm menyatakan bahwa al-Khulu' adalah perceraian suami istri dengan bayaran yang diambil suami dari istrinya atau selainnya dengan lafadz yang khusus. ${ }^{10}$

\section{Hukum Gugat Cerai}

Gugat Cerai atau al-Khulu' disyariatkan dalam syari'at islam berdasarkan kepada firman Allah yang artnya: "Tidak halal bagi kamu mengambil kembali sesuatu dari yang telah kamu berikan kepada mereka, kecuali kalau keduanya kahwatir tidak akan dapat menjalankan bukum-hukum Allah. Jika kamu khawatir bahwa keduanya (suami-isteri) tidak dapat menjalankan bukum-bukum Allah, maka tidak ada dosa atas keduanya tentang bayaran yang diberikan oleh isteri utuk menbus dirinya. Itulah hukum-hukum Allah, maka janganlah kamu melanggarnya. Barangsiapa yang melanggar bukum-bukum Allah mereka itulah orangorang yang ralim." (Qs. Al-Baqarah 2:229)

Dan sabda Rasulullah shallallahu 'alaihi wa sallam dalam hadits Ibnu Abas radbiallabu 'anbuma:

under the circumstances to ask for of its husband that khulu' although has to turn over asset. Since is not equitable a muslimah becomes person wife that have confidence and atheist conduct.

7 Asghar ali Engginer, Pembebasan prempuan, terjemahan Agus nuryanto (Yogyakarta:Lkis,2003),127.

8 Tim Penyusun Buku, Analisis Faktor Penyebab Terjadinya Perceraian, Jakarta 317, Ditbinbanpera Depag RI, 1990, 69-73.

9 Shabih Fikib Sunnah 3/340

10 Taudhih al-Abkâm Min Bulugh al-Marâm, Syeikh Abdullah bin Abdurrahman al-Basâm, cetakan kelima tahun 1423H, Maktabah al-Asadi, Makkah 5/468 


\section{Qawwãm • Volume 13 Nomor 2, Desember 2019}

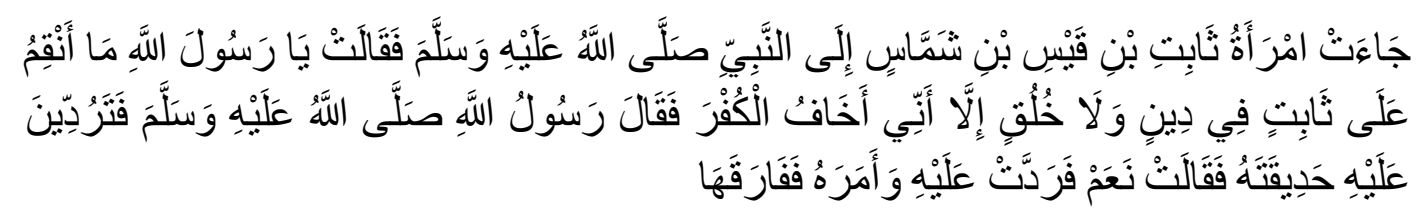

"Datang istri Tsâbit bin Qais bin Syammâs kepada Nabi shallallabu 'alaibi wa sallam lalu berkata: Wahai Rasulullab aku tidak membenci Tsâbit dalam agama dan akblaknya. Aku banya takut kufur. Maka Rasulullah shallallabu 'alaibi wa sallam bersabda: Maukah kamu mengembalikan kepadanya kebunnya? Ia menjawab, Ya. Lalu ia mengembalikan kepadanya dan Rasulullah shallallabu a'laibi wa sallam memerintabkannya dan Tsâbitpun menceraikannya." (HR al-Bukhari).

Berlaku bagi al-Khulu' lima hukum taklifi dalam fikih yaitu: ${ }^{11}$

1. Mubah (diperbolehkan)

Ketentuannya adalah sang wanita sudah benci tinggal bersama suaminya karena kebencian dan takut tidak dapat menunaikan hak suaminya tersebut dan tidak dapat menegakkan batasan-batasan Allah dalam ketaatan kepadanya, dengan dasar firman Allah yang artinya: "Tika kamu khawatir bahwa keduanya (suami-isteri) tidak dapat menjalankan bukum-bukum Allah, maka tidak ada dosa atas keduanya tentang bayaran yang diberikan oleb isteri utuk menebus dirinya." (Qs. Al-Baqarah 2:229)

Ibnu Hajar memberikan ketentuan dengan al-Khulu' ini dengan menyatakan bahwa ia adalah seorang suami menceraikan istrinya dengan penyerahan pembayaran ganti kepada suami. Ini dilarang kecuali dalam keadaan khawatir keduanya atau salah satunya tidak dapat melaksanakan yang diperintahkan Allah. Hal ini bisa muncul dari ketidak sukaan dalam pergaulan rumah tangga, bisa jadi karena jeleknya akhlak atau bentuk jasmaninya. Demikian juga hilang larangan ini apabila keduanya membutuhkan karena khawatir dosa yang menyebabkan al-Bainunah al-Kubra (perceraian besar atau talak tiga). 12 Syeikh al-Basâm menyatakan bahwa diperbolehkan al-Khulu' (gugat cerai) bagi wanita apabila sang istri membenci akhlak suaminya atau khawatir dosa karena tidak dapat menunaikan haknya. Apabila sang suami mencintainya, maka disunnahkan sang istri sabar dan tidak memilih perceraian. ${ }^{13}$

2. Diharamkan khulu' baik dari sisi suami maupun istri

a. Dari sisi suami

Apabila suami menyusahkan sang istri dan memboikotnya atau tidak memberikan hak-haknya dengan sengaja dan sejenisnya agar sang istri membayar kepadanya tebusan dengan jalan gugat cerai. Al-Khulu'nya batil dan tebusannya dikembalikan kepada wanita dan status wanita tetap seperti asalnya, apabila khulu' tidak dengan lafazh talak. Karena Allah berfirman yang artinya: 'Janganlah kamu

${ }_{11}$ Amir, Syarifuddin, Hukum Perkawinan Islam di Indoneia antara Figh Munakahat dan Undangundang Perkawinan. Jakarta: Prenada Media. 2007.

12 Fat-hul Bari 9

13 Taudhih al-Ahkâm 5/469 
menyusabkan mereka karena hendak mengambil kembali sebagian dari apa yang telah kamu berikan kepadanya, terkecuali bila mereka melakukan pekerjaan keji yang nyata." (QS. AnNisaa':19)

Apabila Suami menceraikannya maka ia tidak memiliki hak mengambil tebusan tersebut. Namun bila istri berzina lalu suami membuatnya susah agar istri tersebut membayar tebusan dengan al-Khulu' maka diperbolehkan berdasarkan ayat diatas. $^{14}$

b. Dari sisi istri.

Apabila meminta cerai padahal hubungan rumah tangganya baik dan tidak terjadi perselisihan dan pertengkaran diantara pasangan suami istri serta tidak ada alasan syar'i yang membenarkan adanya khulu', berdasarkan sabda Rasulullah shallallabu 'alaibi wa sallam:

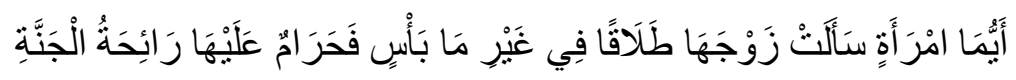

"Semua wanita yang minta cerai (gugat cerai) kepada suaminya tanpa alas an, maka haram baginya wangi syurga." (HR. Abu Daud, al-Tirmidzi, Ibnu Majah dan Ahmad dan dishahihkan al-Albani dalam kitab Irwa' al-Ghalil no. 2035).

3. Mustahabbah (sunnah) wanita minta cerai (al-Khulu')

Apabila suami meremehkan (Mufarrith) hak-hak Allah maka sang istri disunnahkan al-Khulu' menurut madzhab Ahmad bin Hambal.

\section{Wajib}

Terkadang al-Khulu' menjadi wajib hukumnya pada sebagian keadaan seperti orang yang tidak pernah melakukan sholat, padahal telah diingatkan. Demikianlah juga pada masalah, seandainya sang suami memiliki keyakinan atau perbuatan yang dapat mengeluarkannya dari islam dan menjadikannya murtad. Sang wanita tidak mampu membuktikannya dihadapan hakim peradilan untuk dihukumi berpisah atau mampu membuktikannya, namun hakim peradilan tidak menghukuminya murtad dan tidak juga kewajiban berpisah. Maka wajib bagi wanita tersebut dalam keadaan seperti ini untuk meminta dari suaminya tersebut khulu' walaupun harus menyerahkan harta. Karena tidak patut seorang muslimah menjadi istri orang yang memiliki keyakinan dan perbuatan kufur.

Dalam perceraian bukan saja cerai gugat atau khulu' tetapi juga ada cerai talak, adapun rincian hukum talak jika dilihat dari kondisi rumah tangga yang menyebabkan talak itu terjadi adalah: 15

${ }^{14}$ Nail al-Author Min Ahadits Sayyid al-Akbyaar Syarh Muntaqaa al-Akbbaar, Muhammad bin Ali al-Syaukani, tahqiq Muhammad Saalim Haasyim, cetakan pertama tahun 1415 H, Dar al-Kutub al-'Ilmiyah, Bairut 6/260

${ }_{15}$ Al-Jabiri, Bunyah al-'Aql al-'Arabi: Dirasah Tabliliyyah al-Naqdiyyah li al-Nushum al-Ma'rifah fi al-Tsaqafah al-Islamiyyah (Beirut, Cassablanca: al-Markaz al-Tsaqafi al-'Arabi, 1993) hlm. 9 dan 485. Untuk ulasan komparatif yang lebih luas terhadap konsep-konsep lainnya bandingkan dengan Syamsul Anwar, "Epistemologi Hukum Islam dalam al-Mustashfa min Ilm al-Ushul Karya al-Ghazali 


\section{Qawwãm • Volume 13 Nomor 2, Desember 2019}

a. Talak dihukumkan wajib apabila antara suami isteri senantiasa terjadi percekcokan dan ternyata setelah dilakukan pendekatan melalui juru damai (hakam) dari kedua belah pihak, percekcokan tersebut tidak kunjungberakhir. ${ }^{16}$ Dalam keadaan seperti ini, hukum talak adalah wajib karena perkawinan bertujuan untuk menjalin hubungan yang harmonis dan penuh kasih sayang serta menciptakan ketenteraman antara kedua belah pihak.

b. Talak dihukumkan sunnah apabila isteri tidak mau patuh kepada hukum-hukum Allah SWT dan tidak mau melaksanakan kewajibannya, baik sebagai hamba Allah SWT (seperti shalat dan puasa) maupun sebagai isteri (tidak mau melayani suami).

c. Talak dihukumkan haram tatkala suami mengetahui bahwa isterinya akan melakukan perbuatan zina apabila ia menjatuhkan talak isterinya. Dengan menjatuhkan talak tersebut, berarti suami memberi peluang bagi isterinya untuk melakukan perzinaan. Termasuk ke dalam talak yang diharamkan ini adalah menjatuhkan talak isteri dalam keadaan haid, nifas, dan dalam keadaan suci (tidak haid dan tidak nifas) tetapi telah dicampuri lebih dahulu.

d. Talak dihukumkan makruh apabila talak tersebut dijatuhkan tanpa alasan sama sekali. Hal inilah yang dimaksudkan hadits Nabi SAW yang diriwayatkan oleh Imam Abu Dawud, al-Hakim, dan Ibnu Majah dari Abdullah bin Umar. Menurut fukaha, pengertian "dibenci" dalam hadits tersebut menunjukkan makruh.

e. Talak dihukumkan mubah (boleh) apabila talak itu dijatuhkan dengan alasan tertentu, seperti akhlak wanita yang diceraikan itu tidak baik, pelayanannya terhadap suami tidak baik, dan hubungan antara keduanya tidak sejalan, meskipun pertengkaran dapat dihindari. Dalam perkawinan seperti ini, menurut ulama fikih, tujuan perkawinan yang dikehendaki syara' tidak akan tercapai. Oleh karena itu, suami boleh menjatuhkan talaknya.

\section{Faktor Penyebab Gugat Cerai}

Di dalam hukum perdata dijelaskan, bahwa gugat cerai hanya dapat terjadi berdasarkan alasan-alasan yang ditentukan Undang-undang dan harus dilakukan di depan sidang Pengadilan. Dalam kaitannya dengan hal ini ada dua pengertian yang perlu dipahami yaitu istilah "bubarnya perkawinan" dan "perceraian". Perceraian adalah salah satu sebab dari bubarnya atau putusnya perkawinan. Dalam pasal 199 Kitab Undang-undang Hukum Perdata (BW) disebutkan Perkawinan dapat bubar karena: kematian salah satu pihak, keadaan tidak hadirnya suami atau isteri selama 10 Tahun diikuti perkawinan baru isteri atau suami setelah mendapat izin dari hakim, karena putusan hakim setelah adanya perpisahan meja dan ranjang, serta pembuktian bubarnya perkawinan dalam register catatan sipil.. Sedangkan perceraian yang menjadi dasar bubarnya perkawinan adalah perceraian yang tidak didahului oleh perpisahan meja dan ranjang. Tentang hal ini ditentukan dalam pasal 209 Kitab

(450-505/1058-1111)", Disertasi (Yogyakarta: Program Pascasarjana IAIN Sunan Kalijaga, 2000). 139-148Budi Handiyanto. Perkawinan Beda Agama. Yogyakarta. Chaerul Bayan.2003, 72.

16 Sayyid Sabiq, Fiqh al-Sunnah, jilid 2, (Bairut:Dar al-Fikr 1999), 206. 
Undang-undang Hukum Perdata yaitu: Zina baik yang dilakukan oleh suami atau isteri, meningggalkan tempat tinggal bersama dengan sengaja, suami atau isteri dihukum selama 5 tahun penjara atau lebih yang dijatuhkan setelah perkawinan dilaksanakan, salah satu pihak melakukan penganiayaan berat yang membahayakan jiwa pihak lain (suami/isteri). Lebih lanjut dalam pasal $208 \mathrm{KUH}$ Perdata bahwa perceraian tidak dapat dilaksanakan berdasarkan atas persetujuan antara suami dan isteri. Dalam pasal 38 Undang-undang Nomor 1 Tahun 1974 tentang Perkawinan disebutkan bahwa putusnya perkawinan dapat terjadi karena salah satu pihak meninggal dunia, karena perceraian dan karena adanya putusan pengadilan. Dalam pasal 39 ayat (2) ditentukan bahwa untuk melaksanakan perceraian harus cukup alasan. Ketentuan ini dipertegas lagi dalam penjelasan pasal 39 ayat (2) tersebut dan pasal 19 Peraturan pemerintah Nomor 9 tahun 1975 yang mana disebutkan bahwa alasan yang dapat dipergunakan untuk melaksanakan perceraian adalah: Salah satu pihak berbuat zina atau pemabuk, pemadat dan lain sebagainya yang sukar disembuhkan, salah satu pihak meninggalkan pihak yang lain tanpa alasan yang sah atau karena hal lain diluar kemauannya. salah satu pihak mendapat hukuman penjara minimal 5 tahun atau hukuman yang lebih berat setelah perkawinan berlangsung, salah satu pihak melakukan kekejaman atau penganiayaan berat yang membahayakan pihak lain, salah satu pihak mendapat cacat badan atau penyakit yang menyebabkan tidak dapat menjalankan kewajibannya sebagai suami isteri, antara suami isteri terusmenerus terjadi perselisihan dan pertengkaran dan tidak ada harapan akan hidup rukun lagi dalam rumah tangga. Adapun alas an perceraian khususnya cerai gugat adalah sebagai berikut: ${ }^{17}$

1. Faktor penelantaran atau tidak ada tanggung jawab

Istilah penelantaran secara tegas tidak ditemui dalam Undang-undang No. 1 Tahun 1974, maupun dalam Kompilasi Hukum Islam dan PP No 9 Tahun 1975. Istilah ini digunakan dalam UU No. 23 Tahun 2004, Tentang Penghapusan Kekerasan dalam Rumah Tangga. Dalam Pasal 9 (1) UU No. 23 Tahun 2004, disebutkan bahwa "Setiap orang dilarang menelantarkan orang dalam lingkup rumah tangganya, padahal menurut hukum yang berlaku baginya atau karena persetujuan atau perjanjian ia wajib memberikan kehidupan, perawatan, atau pemeliharaan kepada orang tersebut. Secara substansial istilah penelantaran ini memiliki padanan makna dengan apa yang diatur dalam Pasal 116 Kompilasi Hukum Islam dan Pasal 19 huruf b PP No. 9 tahun 1975, disebutkan bahwa, "Salah satu pihak meninggalkan pihak lain selama 2 (dua) tahun berturut-turut tanpa izin pihak lain dan tanpa alasan yang syah atau karena hal lain diluar kemampuannya". ${ }^{18}$

Dilihat dari sisi perspektif teori kekerasan terhadap perempuan, sebagaimana difahami, bahwa bentuk kekerasan terhadap perempuan, jika dibuat pemilahan, maka perempuan mengalami kekerasan dalam tiga area. Pertama, area keluarga (domestik, privat), yang meliputi berbagai bentuk kekerasan, di antaranya kekerasan fisik dalam bentuk pemukulan, pembunuhan, penganiayaan, pengendalian alat

${ }_{17}$ Moh.Idris Ramulyo. Hukum Perkawinan Islam. Bandung. Mondar Maju.1990, 23.

18 Idris Ramulyo, Analisis hokum perkawinan islam, hal 161. 


\section{Qawwãm • Volume 13 Nomor 2, Desember 2019}

produksi; kedua, kekerasan psikhis/emosional, meliputi: penghinaan, pengurungan, perkawinan paksa; ketiga,Kekerasan ekonomi, di anrtaranya tidak memberi nafkah kepada istri dan penelantaran terhadap istri serta anak-anak, maka pada kasus di atas bukan sekedar penelantaran tapi juga telah mamasuki wilayah kekerasan dalam rumah tangga.

\section{Faktor suami selingkuh/ gangguan pihak ketiga}

Meskipun di dalam undang-undang perkawinan, begitu juga menurut Kompilasi hukum Islam, seorang laki-laki dapat beristri lebih dari satu orang asal dapat memenuhi sejumlah persyaratan yang sudah ditentukan, namun tidak sedikit ditemui kasus di mana seorang suami yang sudah beristri menjalin hubungan layaknya suami istri. Dikatakan demikian karena dalam kasus selingkuh pada umumnya meskipun menikah, maka pernikahan itu dilakukan tanpa mengikuti persyaratan yang diwajibkan oleh peraturan perundang-undangan. Atau malah pasangan seperti ini belum diikat dalam suatu perkawinan. Oleh karena itu maka selingkuh merupakan perbuatan yang sangat merusak ikatan perkawinan. Kompilasi Hukum Islam dan Pasal 19 huruf a PP No. 9 tahun 1975, disebutkan bahwa, "salah satu pihak berbuat zina atau menjadi pemabuk, pemadat, pejudi, dan lain sebagainya yang sukar disembuhkan". Namun yang pasti akibat terjadinya selingkuh itu kemudian diikuti dengan serangkaian pertengkaran yang berkelanjutan dan dalam satu kasus juga ada yang diikuti dengan penelantaran. Oleh karena itu untuk mengajukan gugatan cerai haruslah cukup alasan yang dapat di jadikan dasar untuk mangajukan cerai gugat.

3. Faktor Kekerasan/kekejaman dalam rumah tangga baik kekejaman jasmani maupun kekejaman mental

Kekerasan yang dilakukan oleh suami kepada istri atau sebaliknya merupakan perbuatan yang tidak sesuai dengan tujuan perkawinan, oleh karena itu hal ini merupakan alasan yang dapat dijadikan dasar untuk melakukan perceraian sebagaimana diatur dalam Pasal 116 huruf d Kompilasi Hukum Islam dan Pasal 19 huruf d PP No. 9 tahun 1975, yaitu "Salah satu pihak melakukan kekejaman atau pengeniayaan berat yang membahayakan pihak lain".

Kompilasi Hukum Islam maupun PP No 9 Tahun 1975 menggunakan istilah "kekejaman atau pengeniayaan berat", bukan kekerasan dalam rumah tangga. Istilah kekerasan dalam rumah tangga dikenal dalam UU No. 23 Tahun 2004, Tentang Penghapusan Kekerasan dalam Rumah Tangga. Dalam Pasal 1 UU ini disebutkan, bahwa Kekerasan dalam Rumah Tangga adalah setiap perbuatan terhadap seseorang terutama perempuan, yang berakibat timbulnya kesengsaraan atau penderitaan secara fisik, seksual, psikologis, dan/atau penelantaran rumah tangga termasuk ancaman untuk melakukan perbuatan, pemaksaan, atau perampasan kemerdekaan secara melawan hukum dalam lingkup rumah tangga. Dengan demikian pengertian kekerasan dalam rumah tangga menurut UU Penghapusan Kekerasan Dalam Rumah Tangga lebih luas karena tidak saja kekerasan fisik seperti yang dimaksud dalam Pasal 116 huruf d Kompilasi Hukum Islam dan Pasal 19 huruf b PP No. 9 tahun 
1975, tapi juga meliputi kekerasan fisikhis, seksual dan penelantaran rumah tangga.

Sehubungan dengan kasus tersebut di lihat dari latar belakangnya, kekerasan terhadap perempuan lahir karena perempuan dilihat dan di kaitkan dengan lingkup privat (keluarga). Beberapa bentuk kekerasan seperti pemerkosaan, pemukulan istri dan pelecehan seksual menggambarkan anggapan ini. Selama masyarakat melihat bentuk kekerasan ini sebagai bagian dari lingkup privat, maka hukum tidak pernah akan membongkar perilaku ini. ${ }^{19}$

\section{Faktor cemburu}

Salah satu unsur penting untuk dapat mencapai kehidupan rumah tangga yang bahagia dan sejahtera adalah adanya saling percaya antara suami dan istri. Oleh karena itu ketika rasa saling percaya ini mulai hilang diantara pasangan suami istri, maka yang muncul kemudian adalah saling curiga yang terwujud dalam bentuk rasa cemburu. Ada ungkapan yang mengatakan bahwa "cemburu itu tandanya cinta", tidak selamanya benar. Hal ini ketika rasa cemburu itu berlebihan yang kemudian berubah dengan rasa curiga yang menganggap istri melakukan suatu yang tidak benar, maka yang muncul kemudian adalah pertengkaran yang berkelanjutan.

Di dalam Kompilasi Hukum Islam maupun PP No. 9 tahun 1975, rasa cemburu bukanlah merupakan faktor yang dapat diajukan sebagai alasan untuk mengajukan perceraian. Meskipun demikian persoalannya bukan selesai pada rasa cemburu. Karena rasa cemburu itu kemudian diikuti dengan serangkaian pertengkaran yang berkelanjutan dan dalam satu kasus juga ada yang diikuti dengan penelantaran bahkan kekerasan terhadap istri. Hal ini diatur dalam Pasal 116 Kompilasi Hukum Islam dan Pasal 19 huruf f PP No. 9 tahun 1975, disebutkan bahwa, "antara suami istri terus menerus terjadi perselisihan dan pertengkaran dan tidak ada harapan untuk hidup rukun lagi dalam rumah tangga" Oleh karena itu cemburu yang berlebihan dapat dipandang sebagai faktor penyebab terjadainya cerai gugat.

\section{Faktor Suami Sering Tidak Jujur.}

Faktor kejujuran memegang peran penting dalam suatu rumah tangga. Oleh karena itu ketika salah satu pihak baik suami maupun istri berlaku tidak jujur, dan ketidak jujuran itu diketahui oleh salah satu pihak, maka dapat menimbulkan konflik rumah tangga. Ketidak jujuran suami telah menimbulkan akibat ketidak harmonisan dalam rumah tangga. Meskipun ketidak jujuran tidak sebut sebagai syarat yang dapat diajukan sebagai alasan mengajukan cerai, sebagai mana diatur dalam PP No 9 Tahun 1975 dan Kompilasi Hukum Islam, namun dampak dari ketidak jujuran itu membawa pertengkaran terus menerus serta dampak lainnya seperti suami meninggalkan istri, maka hal inilah yang dijadikan sebagai dasar untuk mengajukan perceraian. Hal ini diatur dalam Pasal 116 Kompilasi Hukum Islam dan Pasal 19 huruf f PP No. 9 tahun 1975, disebutkan bahwa, "antara suami istri terus menerus terjadi perselisihan dan pertengkaran dan tidak ada harapan untuk hidup rukun lagi

19 Sita Aripurnami, Perempuan dan Pemberdayaan. Program Studi kajian Wanita UI. Jakarta, 1997.hal. 34 . 


\section{Qawwãm • Volume 13 Nomor 2, Desember 2019}

dalam rumah tangga”.

6. Faktor suami penjudi dan peminum minuman keras atau krisis ahlak

Judi merupakan penyakit masyarakat yang juga berdampak pada kehidupan rumah tangga. Oleh karena itulah di dalam Pasal 19 PP No. 9 Tahun 1975 judi merupakan salah satu faktor yang dapat dijadikan alasan untuk mengajukan gugatan cerai. Berdasarkan kasus yang dipelajari terlihat bahwa akibat suami yang penjudi mengakibatkan cekcok dan pertengkaran, bahkan lebih jauh lagi perekonomian keluarga menjadi sulit. Dalam kasus ini perilaku tergugat sulit disembuhkan terbukti dari kenyataan bahwa meskipun sudah dipindahkan ke kota lain namun kegemaran berjudi dari tergugat juga tidak berubah. Oleh karena itu dalam kasus ini memang sudah cukup alasan untuk mengajukan gugat cerai sebagaimana diatur dalam dalam Pasal 116 Kompilasi Hukum Islam dan Pasal 19 huruf a PP No. 9 tahun 1975, disebutkan bahwa, "salah satu pihak berbuat zina atau menjadi pemabuk, pemadat, pejudi, dan lain sebagainya yang sukar disembuhkan”. Adapun yang menjadi faktor penentu adalah adanya kesadaran bagi istri akan hak-haknya sebagai istri dan sebagai individu yang berhak untuk diperlakukan secara adil, dalam keluarga. Pengetahuan jender dipandang sebagai faktor yang berpengaruh dalam menentukan keputusan perempuan, persepsi dan kehidupan perempuan, membentuk kesadarannya, keterampilannya dan membentuk pola hubungan antara laki-laki dan perempuan. Hal ini disebabkan oleh beberapa faktor seperti menolak untuk berhubungan seksual, suami selingkuh, cemburu, dan ingin kawin lagi.

\section{Faktor Ekonomi}

Alasan ekonomi (uang belanja rumah tangga) juga merupakan salah satu pemicu perceraian, terutama cerai gugat. Suami yang tidak bisa memberikan nafkah lahir kepada istri dan anak-anak baik karena alas an logis sekalipun misalnya seperti dipecat dari pekerjaannya mungkin bisa diterima dan berusaha untuk mencari pekerjaan lain, akan tetapi kalau sifat malas suami dalam mencari nafkah mungkin ini yang tidak bisa di tolerir lagi. Akan tetapi ketika kedua belah pihak menyadari dan bekerjasama dalam memenuhi kebutuhan keluarga maka kata perceraian tidak aka nada.

\section{Kawin dibawah umur}

Berkenaan dengan usia saat menikah sebagian besar tergolong pada usia muda, yaitu berkisar antara 16-20 tahun. Pada usia ini meskipun menurut UU Perkawinan telah memenuhi syarat untuk menikah, namun dari sisi fisik dan fisikhis sebenarnya belum cukup siap untuk menikah. Sedangkan usia saat bercerai relatif menyebar mulai pada rentang usia 16-20 sampai dengan usia di atas 40 tahun, dengan angka tertinggi pada rentang usia 36-40 tahun. Hal ini menandakan bahwa usia perkawinan yang dijalani ada yang berjalan singkat namun ada pula yang cukup panjang. Faktor lainnya adalah karena pada umumnya istri tidak memiliki penghasilan tetap, sehingga tindakan ketergantungannya dengan suami cukup tinggi, sehingga istri merasa khawatir akan terlantar jika bercerai. 
Selisih umur sebenarnya merupakan jarak usia yang ideal, namun faktanya terjadi juga perceraian. Hal ini menunjukkan bahwa faktor selisih umur laki-laki yang lebih tua bukanlah penentu dalam mewujudkan keluarga yang kekal. Dengan demikian ada kecenderungan bahwa perceraian tertinggi terjadi pada rentang usia perkawinan 1-5 tahun, dan semakin lama rentang perkawinan, cenderung terus menurun jumlah perceraian yang terjadi. Hal ini dapat dikaitkan dengan semakin tua usia seorang semakin matang dan arif dalam mengantasi permasalahan dalam keluarga.

9. Faktor dihukum, cacat biologis dan politis

Alasan seperti yang telah diuraikan pada penjelasan ayat 2 dari pasal $39 \mathrm{UU}$ Nomor 1 tahun 1974 dan yang ada pada pasal 19 huruf (a-f) PP Nomor 9 tahun 1975 , ternyata masih belum mencakup alas an-alasan yang ada, ${ }^{20}$ masih ada alas analasan lainnya namun tidak tercakup dalam ketentuan ini. Maka kekurangankekurangan ini kemudian disempurnakan dalam Kompilasi Hukum Islam. Setidaknya ada dua point yang ditambahkan dalam ketentuan ini. Pertama, suami melanggar taklik talak dan kedua, peralihan agama atau murtad, yang menyebabkan terjadinya ketidakrukunan dalam rumah tangga (pasal 116 huruf g dan h KHI). ${ }^{21}$

\section{Proses Pelaksanaan Dan Keputusan Gugat Cerai}

Gugat cerai hanya dapat dilakukan di depan sidang pengadilan agama setelah pengadilan agama tersebut berusaha dan tidak berhasil mendamaikan kedua belah pihak". Perceraian selalu menjadi solusi retaknya sebuah rumah tangga. Pasal 38 UU No. 1 Th. 1974, menentukan bahwa pada perjalanannya, perkawinan dapat saja berakhir, yaitu jika disebabkan oleh kematian, perceraian atau keputusan pengadilan. Perceraian hanya dapat terjadi apabila dilakukan di depan Pengadilan Agama, baik itu karena suami yang menjatuhkan cerai (talak), ataupun karena isteri yang menggugat cerai atau memohon hak talak sebab sighat taklik talak. Meskipun dalam agama Islam, perkawinan yang putus karena perceraian dianggap sah apabila diucapkan seketika oleh suami, namun harus tetap dilakukan di depan pengadilan. Tujuannya adalah untuk melindungi segala hak dan kewajiban yang timbul sebagai

${ }^{20}$ Mengenai alasan perceraian dan alat bukti untuk mengajukan gugatan diatur dalam pasal 73,74, 75, dan 76 UUPA dan pasal 133, 134 dan 135 KHI. Pada Pasal 73 UUPA dijelaskan : (1) Gugatan perceraian diajukan oleh isteri atau kuasanya kepada pengadilan yang daerah hukumnya meliputi tempat kediaman penggugat, kecuali apabila penggugat dengan sengaja meninggalkan tempat kediaman bersama tanpa izin tergugat. (2) Dalam penggugat bertempat kediaman di luar negeri gugatan perceraian diajukan kepada pengadilan yang daerah hukumnya meliputi tempat kediaman tergugat. (3) Dalam hal penggugat dan tergugat bertempat kediaman di luar negeri, maka gugatan diajukan kepada pengadilan yang daerah hukumnya meliputi perkawinan mereka dilangsungkan atau ke Pengadilan Agama Jakarta pusat. Pada Pasal 74 UUPA menyatakan: Apabila gugatan perceraian didasarkan atas alasan salah satu pihak mendapat pidana penjara, maka untuk memperoleh putusan perceraian, sebagai bukti penggugat cukup menyampaikan salinan putusan pengadilan yang berwenang yang memutuskan perkara disertai keterangan yang menyatakan bahwa putusan itu telah memperoleh kekuatan hukum tetap.

${ }^{21}$ Abdurrahman, Kompilasi Hukum Islam di Indonesia, hal.140-141 


\section{Qawwãm — Volume 13 Nomor 2, Desember 2019}

akibat hukum perceraian itu. Sebelum mengambil keputusan untuk melakukan gugatan perceraian ada beberapa hal yang seharusnya diperhatikan diantaranya:

1. Proses pemantapan niat, menyediakan dana dan waktu Bagaimanapun perceraian merupakan keputusan yang membutuhkan pemikiran serius, kedewasaan bertindak serta niat yang kuat untuk menjalaninya mau tidak mau perceraian akan melahirkan sejumlah dampak yang serius, baik secara psikologis, yuridis dan sosiologis, namun juga kepada anak dan keturunannya. Untuk itu kemantapan niat harus dibutuhkan pula tentang penyediaan dana, untuk mengajukan permohonan gugatan cerai. Terkait dengan biaya pendaftaran permohonan gugatan sampai kepada biaya transportasi maupun jasa bantuan advokat/pengacara yang akan mendampinginya.

2. Meminta Pertimbangan dari beberapa orang terdekat. Sekalipun seorang sudah memantapkan niatnya untuk mengajukan permohonan atau gugatan perceraian, namun tidak ada salahnya bila meminta pendapat dari sejumlah orang terdekat, paling tidak untuk memperkuat alasan perceraian baik cerai gugat mauapun cerai talak.

3. Menentukan perlu tidaknya kuasa hukum atau pengacara. Keberadaan kuasa hukum atau pengacara harus dipertimbangkan secara matang. Tidak saja terkait dengan dana yang harus disiapkan untuk membayar jasa pendampingnya, namun juga mengingat efektifitas penggunaan jasa hukum. Maka hal ini, keberadaan kuasa hukum sangat membantu kelancaran proses perkara.

4. Mengajukan surat pemberitahuan atas surat permohonan perceraian Bila semua sudah disiapkan, dan niat untuk mengajukan gugatan perceraian sudah mantap, maka selanjutnya menyusun gugatan permohonan perceraian, dimulai dengan kronologis perkawinan, alasan yang menyebabkan (posita), disertai atas permohonan putusan yang akan diperoleh nantinya (petitum) kemudian diajukan ke Pengadilan Agama tempat pemohon berdomisili/ bermukim.

5. Melakukan proses sidang perceraian, proses sidang perceraian bisa dilakukan, bila gugatan atau permohonan cerai sudah didaftarkan dan deregister oleh panitera pengadilan yang berwenang mengadilinya. kemudian ketua pengadilan terkait, akan menunjuk majelis hakim yang bertugas untuk menyidangkan kasus tersebut. Sekaligus menentukan jadwal sidang pertama dari gugatan tersebut.

Pada Pasal 75 UUPA menyatakan: Apabila gugatan perceraian didasarkan atas alasan bahwa tergugat mendapat cacat badan atau penyakit dengan akibat tidak dapat menjalankan kewajiban sebagai suami, maka hakim dapat memerintahkan tergugat untuk memeriksakan diri kepada dokter. Pasal 76 UUPA : Pengadilan setelah mendengar keterangan saksi tentang sifat persengketaan antara suami isteri dapat mengangkat seorang atau lebih dari keluarga masing-masing pihak ataupun orang lain untuk menjadi hakam. Pasal 77 UUPA : Selama berlangsungnya gugatan perceraian, atas permohonan penggugat atau tergugat atau berdasarkan pertimbangan bahaya yang mungkin ditimbulkan, pengadilan dapat mengizinkan suami isteri tersebut untuk tidak tinggal dalam satu rumah. Pasal 78 UUPA : Selama berlangsungnya gugatan perceraian atas permohonan penggugat, pengadilan dapat: 
1.Menerima nafkah yang ditanggung suami, 2.Menentukan hal-hal yang perlu untuk menjamin pemeliharaan dan pendidikan anak, 3.Menentukan hal-hal yang perlu untuk menjamin terpeliharanya barang-barang yang menjadi hak bersama suami isteri atau barang-barang yang menjadi hak suami atau barang-barang yang menjadi hak isteri. Gugatan tersebut gugur apabila suami atau isteri meninggal sebelum adanya putusan pengadilan mengenai gugatan perceraian itu. Namun bila terjadi perdamaian, tidak dapat diajukan gugatan perceraian baru berdasarkan alasan yang ada dan telah diketahui oleh penggugat sebelum perdamaian tercapai. Upaya damai dimaksud, memungkinkan terjadi, mengingat ia tidak dibatasi pada sebelum pemeriksaan perkara, namun dapat diupayakan setiap kali sidang. Lain halnya bila tidak tercapai perdamaian, pemeriksaan gugatan perceraian dilakukan dalam sidang tertutup. Mengenai pelaksanaan sidang pemeriksaan gugatan penggugat dimulai selambat-lambatnya 30 (tiga puluh hari) setelah berkas atau surat gugatan perceraian didaftarkan di kepaniteraan. Hal itu diatur dalam pasal 80 ayat (1) UUPA: (1) Pemeriksaan gugatan perceraian dilakukan oleh Majelis Hakim selambat-lambatnya 30 (tiga puluh) hari setelah berkas atau gugatan perceraian didaftarkan di kepaniteraan. Lain halnya pasal 80 ayat (2) dan (3) hanya menjelaskan teknis untuk menghindarkan ketidakhadiran pihak-pihak yang berperkara baik penggugat maupun tergugat. Hal itu, menunjukkan hanya merupakan penegasan pasal $29 \mathrm{PP}$ ayat (2) dan (3) sebagai berikut: (2)Dalam penetapan waktu sidang gugatan perceraian, perlu diperhatikan tenggang waktu pemanggilan dan diterimanya panggilan tersebut oleh penggugat maupun tergugat atau kuasa mereka (3)Apabila tergugat berada dalam keadaan seperti dalam pasal 116 huruf b, sidang pemeriksaan gugatan perceraian diterapkan sekurang-kurangnya 6 (enam) bulan terhitung sejak dimasukkannya gugatan perceraian pada kepaniteraan pengadilan agama. Kalau sidang pemeriksaan gugatan perceraian dilakukan secara tertutup, putusan pengadilan mengenai gugatan dimaksud diucapkan dalam sidang terbuka untuk umum. Perceraian dianggap terjadi, beserta segala akibat hukum tetap. Karena itu kehadiran pihak-pihak yang berperkara atau wakil/kuasanya menjadi faktor penting kepada lancarnya pemeriksaan perkara di persidangan. Hal ini diuraikan dalam pasal $142 \mathrm{KHI}$, yang berbunyi: (1)Pada sidang pemeriksaan gugatan perceraian, suami isteri datang sendiri atau mewakilkan kepada kuasanya, (2) Dalam hal suami atau isteri mewakilkan, untuk kepentingan pemeriksaan hakim dapat memerintahkan yang bersangkutan untuk hadir sendiri. Sesudah perkara perceraian diputuskan dalam sidang terbuka untuk umum, maka salinan putusan dikirim kepada pihak-pihak terkait. Karena itu pasal 147 KHI menjelaskan sebagai berikut: (1) Setelah perkara perceraian itu diputuskan, maka panitera Pengadilan Agama menyampaikan salinan surat putusan tersebut kepada suami isteri atau kuasanya dengan menarik kutipan Akta Nikah dari masing-masing yang bersangkutan. Selain salinan putusan dikirim kepada suami isteri tersebut, dijelaskan dalam Pasal 84 UUPA: (1) Panitera pengadilan atau pejabat pengadilan yang ditunjuk berkewajiban selambat-lambatnya 30 (tiga puluh) hari mengirimkan satu helai salinan putusan pengadilan yang telah memperoleh kekuatan hukum tetap, tanpa bermaterai kepada pegawai pencatat nikah yang wilayahnya meliputi tempat kediaman penggugat dan tergugat, untuk mendaftarkan putusan 


\section{Qawwãm • Volume 13 Nomor 2, Desember 2019}

perceraian dalam sebuah daftar yang disediakan untuk itu. (2)Apabila perceraian dilakukan di wilayah yang berbeda dengan wilayah pegawai pencatat nikah tempat perkawinan dimaksud dalam ayat satu yang telah memperoleh kekuatan hukum tetap tanpa bermaterai dikirimkan pula kepada Pegawai Pencatat Nikah di tempat perkawinan dilangsungkan dan oleh Pegawai Pencatat Nikah tersebut pada bagian pinggir daftar catatan perkawinan. (3)Apabila perkawinan dilangsungkan di luar negeri, maka satu helai salinan putusan sebagaimana yang dimaksud dalam ayat satu disampaikan pula kepada Pegawai Pencatat Nikah di tempat didaftarkannya perkawinan mereka di Indonesia (4)Panitera berkewajiban memberikan akta cerai sebagai surat bukti cerai kepada para pihak selambat-lambatnya 7 (tujuh) hari terhitung setelah putusan yang memperoleh kekuatan hukum tetap tersebut diberitahukan kepada para pihak. Lain halnya, bila terjadi kelalaian pengiriman salinan putusan sebagaimana yang dimaksud dalam pasal 84 menjadi tanggung jawab panitera yang bersangkutan atau pejabat pengadilan yang ditunjuk, apabila yang demikian itu mengakibatkan kerugian bagi bekas suami atau isteri atau keduanya. Karena itu amat penting pengiriman salinan putusan dimaksud. Sebab akan mendatangkan kerugian dari berbagai pihak yang membutuhkannya. ${ }^{22}$

\section{Dampak Gugat Cerai Terhadap Harta Bersama dan Pengasuhan Anak}

Dalam hukum Islam maupun hukum Belanda, perceraian yang terjadi antara seorang suami dan isteri bukan hanya memutuskan ikatan perkawinan saja, lebih lanjut perkawinan juga melahirkan beberapa akibat seperti timbulnya pembagian harta bersama (gemenshap) dan hak pengurusan anak (hadlonah).

\section{Dampak Gugat Cerai Terhadap Harta Bersama}

Perceraian yang timbul antara suami dan isteri melahirkan akibat, diantaranya adalah pembagian harta bersama. Dalam bahasa Belanda disebut gemenschap. Sebenarnya konsep harta bersama dalam hukum Islam tidak ditemukan nash yang secara tegas menyebutkan hukum harta bersama baik dalam al-Qur'an maupun hadist. Karenanya hal ini merupakan ranah ijtihad bagi ulama yang memiliki kapasitas untuk melakukan ijtihad atau yang dikenal dengan istilah mujtahid, ada dua kultur yang berlaku, pertama; kultur masyarakat yang memisahkan antara harta suami dan harta isteri dalam sebuah rumah tangga. Dalam masyarakat muslim seperti ini, tidak ditemukan adanya istilah harta bersama. Kedua; masyarakat muslim yang tidak memisahkan harta yang diperoleh suami isteri dalam pernikahan. Masyarakat muslim seperti ini mengenal dan mengakui adanya harta bersama. Di Indonesia, adat kebiasaan masyarakat muslim yang mengakui adanya harta bersama sudah menjadi lebih kuat, karena telah dituangkan dalam pasal 35 ayat (1) Undang-undang Nomor 1 tahun 1974. Sedangkan dalam hukum Belanda yang terdapat dalam Pasal 119 dan Pasal 126 Burgerlijk Wetboek disebutkan bahwa sejak saat dilangsungkan perkawinan, maka menurut hukum, terjadilah percampuran harta antara suami isteri yang disebut dengan harta bersama. Hal ini terjadi selama tidak ditentukan lain

22 Ahmad Rofiq, Hukum Islam di Indonesia, (Jakarta: PT RajaGrafindo Persada, 1998), hal. 287- 288 . 
dalam perjanjian perkawinan. Harta bersama bubar atau berakhit demi hukum disebabkan; kematian salah satu pihak, perceraian, pisah meja dan ranjang dan karena pemisahan harta yang dituangkan dalam perjanjian sebelum terjadinya perkawinan. Dan dalam Pasal 127 BW, setelah bubarnya harta bersama, kekayaan mereka dibagi dua antara suami dan isteri atau antara para pewaris mereka tanpa mempersoalkan dari pihak mana asal barang-barang itu.

\section{Dampak Gugat Cerai Terhadap Pengasuhan Anak}

Perceraian disamping menimbulkan adanya pembagian harta bersama seperti yang diterangkan diatas, juga menimbulkan masalah pengurusan anak. Pengurusan anak atau dikenal dengan sebutan hadlonah. Hukum Islam menyebutkan bahwa apabila terjadi perceraian antara suami dan isteri, maka isterilah yang berhak mengasuh mendidik dan memelihara anak-anaknya selama anak-nya belum mumayyiz. Hal ini berdasarkan Sabda Nabi kepada seorang isteri yang mengadukan pengurusan anaknya setelah isteri tersebut bercerai dari suaminya. Nabi berkata:"kaulah yang lebih berbak mendidik anakmu selama kamu belum kawin dengan orang lain”. (Hadits riwayatAbu Dawud dan al-Hakim).

Apabila dalam suatu perkawinan telah memperoleh anak, maka bila terjadi perceraian antara suami istri, maka hal ini akan berdampak terhadap perkembangan psikoligis anak. Hal ini terutama jika anak-anak tersebut masih belum dewasa. UU No. 1 Tahun 1974 maupun Kompilasi Hukum Islam mengatur secara ketat mengenai status anak jika terjadi perceraian. Keputusan tersebut jika ditinjau dari sisi perlindungan terhadap anak maupun terhadap wanita sebagai ibunya jelas kurang memberikan kepastian. Karena nantinya jadi sulit bagi ibu dan anak untuk menuntut kepada ayahnya. Padahal secara tegas Pasal 41 Undang-undang No. 1 tahun 1974 menetukan kewajiban ibu dan bapaknya terhadap anak-anaknya adalah sebagai berikut:

a. Baik ibu atau bapak tetap berkewajiban memelihara dan mendidik anakanaknya, semata-mata berdasarkan kepentingan sianak, bilamana ada perselisihan mengenai penguasaan anak-anak. Pengadilan memberikan Keputusannya.

b. Bapak yang bertangung jawab atas semua biaya pemeliharaan dan biaya yang diperlukan anak itu, bilamana bapak dalam kenyataan tidak dapat memberi kewajiban tersebut Pengadilan dapat menentukan bahwa ibunya ikut memikul biaya tersebut.

c. Pengadilan dapat mewajibkan pada bekas suami untuk memberikan biaya penghidupan dan atau menentukan sesuatu kewajiban bagi bekas istri.

Begitu pula berdasarkan Kompilasi Hukum Islam bahwa Pengadilan dapat pula dengan mengingat kemampuan ayahnya menetapkan jumlah biaya untuk pemeliharaan dan pendidikan anak-anak yang tidak turut padanya. Karena keluarga merupakan lingkungan sosial pertama bagi anak yang memberi dasar perilaku perkembangan sikap dan nilai kehidupan dari keluarga. Salah satunya adalah belajar menghormati orang yang lebih tua serta orang tua membantu menyelesaikan berbagai masalah yang timbul. Orangtua diharapkan dapat membantu anak dalam 


\section{Qawwãm • Volume 13 Nomor 2, Desember 2019}

menyesuaikan diri dengan lingkungan untuk mengatasi masalah secara realistik dan simpati. Oleh karena itu, keluarga sebagai tempat untuk mengkondisikan pemberian nilai positif pada anak. Namun disisi lain, keluarga sering kali menjadi sumber konflik bagi sejumlah orang. Suasana keluarga yang tidak harmonis sering mendorong terjadinya konflik antara kedua orang tua. Salah satu hal yang menjadi ketakutan besar bagi seorang anak adalah perceraian orangtua.

Perceraian yang terjadi pada pasangan suami istri, apapun alasannya, akan selalu berakibat buruk pada anak, meskipun dalam kasus tertentu perceraian dianggap merupakan alternatif terbaik daripada membiarkan anak tinggal dalam keluarga dengan kehidupan pernikahan yang buruk Perceraian antara sepasang suami istri hanya dapat dilakukan di depan sidang pengadilan setelah pengadilan yang bersangkutan berusaha dan tidak berhasil mendamaikan kedua belah pihak dan untuk melakukan perceraian harus ada cukup alasan, bahwa pasangan suami istri itu tidak akan dapat hidup rukun sebagai suami istri. ${ }^{23}$ Perceraian orangtua dianggap sebagai salah satu penyebab utama kegagalan masa depan anak. Anak dapat kehilangan orientasi masa depan karena kehilangan kasih sayang orangtua. Pada umumnya setiap anak menginginkan keutuhan keluarga. Perceraian merupakan kegagalan dalam mengembangkan dan menyempurnakan cinta antara suami-istri. Perceraian merupakan pengalaman yang menyedihkan dan menyakitkan pada suami, istri maupun anak-anak. ${ }^{24}$

Tingkat stres tinggi dikombinasikan dengan hambatan-hambatan yang disebabkan oleh perceraian dapat mengganggu perkembangan ini menjadi tonggak kebingungan. Kesulitan utama yang dialami anak-anak muda adalah bagaimana mereka bisa mengatasi kecenderungan alami untuk menyadari perbedaan yang teramat tipis antara masa muda dengan kanak-kanak yaitu dengan menghindari masalah yang relevan sesuai periodenya.

Tidak dipungkiri memang, bahwa kebahagiaan keluarga bukan semata-mata kebahagiaan bagi anak. Pasangan suami istri juga berhak merasakan kebahagiaan dari pernikahan yang mereka bangun. Ketika pernikahan dirasa tidak lagi mendatangkan kebahagiaan dan tidak dapat lagi menyatukan prinsip-prinsip yang mendasar, perceraian bisa diambil sebagai alternatif pemecahan masalah. Namun demikian, tetap harus dipahami bahwa alternatif tersebut selalu mendatangkan konsekuensi negatif bagi seluruh anggota keluarga. Bagi anak, anggota terlemah dalam keluarga, perceraian selalu saja merupakan rentetan goncangan-goncangan yang menggoreskan luka batin yang dalam. Stres, ketakutan, kecemasan sampai dengan depresi seringkali dialami anak-anak yang kedua orangtuanya bercerai.

Kondisi-kondisi emosi tersebut timbul akibat rasa sakit yang timbul akibat perceraian. Rasa sakit yang ada pada diri individual yang kemudian menjadi pemicu ketidakstabilan emosi. Anak akan mengembangkan kebencian pada kejadian, ataupun pihak-pihak yang menimbulkan rasa sakit tersebut. Perceraian tidak hanya

23 Undang-Undang Perkawinan No 1 Tahun 1974 Pasal 39

24 Sobri Mersi Al-paqi, Solusi Problematika Rumah Tangga Modern (Surabaya: Pustaka Yasir) 
akan menimbulkan kebencian pada kedua orang tua, tapi juga pada dirinya sendiri. Sehingga, anak akan berusaha "menjauhi" orang tua dan dirinya sendiri. Salah satu upaya yang dapat dilakukan untuk mengatasi hal tersebut adalah melalui proses pemaafan (forgiveness) terhadap pihak-pihak yang telah menimbulkan rasa sakit yang ada. Permasalahan yang kemudian menyertai usaha mendorong anak melakukan pemaafan adalah keterbatasan abstraksi anak terhadap emosi yang dimiliki. Anak harus memahami kondisi emosi yang sedang dialami, sebelum kemudian melakukan regulasi terhadap bentuk emosi tersebut, untuk dapat melakukan pemaafan. Dengan keterbatasan kemampuan abstraksinya, memberikan pengertian dan penjelasan bukanlah jalan yang efektif. Pretend play merupakan salah satu jalan bagi anak untuk dapat mengubah pemahamannya terhadap makna peristiwa yang dialaminya. Bermain merupakan representasi dunia anak. Dengan bermain anak mengembangkan pengetahuan dan ketrampilan yang diperlukan dalam menghadapi semua permasalahan-permasalahan yang ditemui. Melalui permainan pura-pura tersebut diharapkan dapat disampaikan alternatif model perilaku dan pemecahaan masalah yang dihadapi dengan rasa sakit akibat perceraian.

Selain dampak negative cerai gugat ada juga dampak positif khususnya bagi kedua belah pihak dan anak-anak, untuk istri mungkin bisa mengakhiri penderitaan kalau dia sering mengalami tindak kekerasan dari suaminya. Bagi anak korban perceraian cendrung lebih mandiri dan bersikap lebih dewasa.

Disamping dua akibat perceraian diatas, khusus dalam hukum Islam ada akibat-akibat lain yang timbul dari perceraian yang tidak ada dalam Hukum Belanda. Dalam hukum Islam ada ciri khas yang tidak ada dalam Hukum Belanda bahwa perceraian tidak sekaligus memutus hubungan suami isteri terutama perceraian dalam bentuk talak raj'i yang memberikan hak ruju' kepada suami sebelum masa 'iddah-nya habis.

Untuk lebih jelasnya implikasi yang ditimbulkan perceraian dalam konsep hukum Islam selain yang telah dipaparkan diatas, penulis akan paparkan sebagai berikut: 25

\section{Akibat Talak Raj'i}

Talak raj'i tidak menghalangi mantan suami berkumpul dengan mantan isterinya, sebab akad perkawinannya tidak hilang dan tidak menghilangkan hak (pemilikan), serta tidak mempengaruhi hubungannya yang halal (kecuali persetubuhan). Segala akibat hukum talak baru berjalan sesudah habis masa 'iddah dan jika tidak ada ruju'. Sedangkan apabila masa 'iddah telah habis maka tidak boleh ruju'dan berarti perempuan itu telah ter-talak ba'in. Jika masih ada dalam masa 'iddah maka talak raj'i yang berarti tidak melarang suami berkumpul dengan isterinya kecuali bersengggama. Jika ia menggaulinya istrinya berarti ia telah ruju'. Selama dalam masa 'iddah, isteri yang ditalak raj'i masih berhak memperoleh tempat tinggal, pakaian, dan uang belanja dari mantan suaminya. Dan selama dalam masa 'iddah bekas isteri wajib menjaga dirinya, tidak menerima pinangan dan tidak menikah dengan pria lain.

25 Abdul Muhaimin As’ad.Risalah Nikah. Surabaya. Bintang Terong.1993, 3. 


\section{Qawwãm• Volume 13 Nomor 2, Desember 2019}

\section{Akibat Talak Bain Shugra}

Talak Ba'in Sughra menghilangkan pemilikan bekas suami terhadap bekas isterinya tetapi tidak menghilangkan kehalalan bekas suami untuk menikahi kembali dengan mantan isterinya, artinya bekas suami boleh mengadakan akad nikah baru dengan bekas isteri, baik dalam masa 'iddah-nya maupun sesudah berakhir masa iddah-nya. Termasuk talak ba'in sughra adalah talak qabla dukbul, talak dengan penggantian harta atau yang disebut dengan khulu, talak karena cacat badan, karena salah seorang dipenjara dan talak karena penganiayaan.

\section{Akibat Talak Ba'in Kubra.}

Hukum talak bain kubra sama dengan talak ba'in sughra, yaitu memutuskan hubungan tali perkawinan antara suami dan isteri. Tetapi talak bain kubra tidak menghalalkan bekas suami merujuk mantan isterinya, kecuali sesudah ia menikah dengan laki-laki lain dan telah bercerai sesudah dikumpulinya, tanpa ada niat tahlil.

\section{Akibat Li'an}

Akibat li'an adalah terjadinya perceraian antara suami isteri. Bagi suami, maka isterinya menjadi haram untuk selamanya. Ia tidak boleh rujuk ataupun menikah lagi dengan akad baru. Bila isterinya melahirkan anak yang dikandungnya, maka anak itu dihukumkan tidak termasuk keturunan suaminya.

\section{Akibat Fasakh}

Pisahnya suami isteri akibat fasakh berbeda dengan yang diakibatkan oleh talak. Sebab talak ada talak bain dan ada talak raj'i. Talak raj'i tidak mengakhiri ikatan suami isteri dengan seketika sedangkan talak ba'in mengakhirinya seketika itu juga. Adapun fasakh, baik karena hal-hal yang datang belakangan maupun karena adanya syarat-syarat yang tidak terpenuhi, maka ia mengakhiri ikatan pernikahan seketika itu juga.

\section{Akibat khulu'}

Khulu' adalah perceraian dengan disertai sejumlah harta sebagai 'iwadh yang diberikan oleh isteri kepada suaminya untuk menebus diri agar terlepas dari ikatan perkawinan. Perceraian antara suami dan isteri akibat khulu', suami tidak bisa meruju' isterinya pada masa 'iddah.

\section{Solusi Membina Keluarga Samawa}

Meski seseorang gagal karirnya di luar rumah, tetapi sukses membangun keluarga yang kokoh dan sejahtera, maka tetaplah ia dipandang sebagai orang yang sukses dan berbahagia. Sebaliknya orang yang sukses di luar rumah, tetapi keluarganya berantakan, maka ia tidak disebut orang yang beruntung, karena betapapun sukses diraih, tetapi kegagalan dalam rumah tangganya akan tercermin di wajahnya, tercermin pula pada pola hidupnya yang tidak bahagia. Hidup menjadi gelisah, tak tenang karena kegagalannya dalam membina rumah tangga. Itulah sebabnya Pasangan ideal dari kata keluarga adalah bahagia, sehingga idiomnya 
menjadi keluarga bahagia. Maknanya, tujuan dari setiap orang yang membina rumah tangga adalah mencari kebahagiaan hidup. Hampir seluruh budaya bangsa menempatkan kehidupan keluarga sebagai ukuran kebahagiaan. ${ }^{26}$

Menikah tidak terlalu sulit, tetapi membangun keluarga bahagia bukan sesuatu yang mudah. Pekerjaan membangun, pertama harus didahului dengan adanya gambar yang merupakan konsep dari bangunan yang diinginkan. Gambar bangunan bisa didiskusikan dan diubah sesuai dengan konsep fikiran yang akan dituangkan dalam wujud bangunan itu. Demikian juga membangun keluarga bahagia, terlebih dahulu orang harus memiliki konsep tentang keluarga bahagia. Ada 5 konsep membangun keluarga bahagia sebagai upaya penanggulangan gugat cerai adalah sebagai berikut: ${ }^{27}$

1. Dalam keluarga itu ada mawaddah dan rahmah (Q/30:21). Mawaddah adalah jenis cinta membara, yang menggebu-gebu dan "nggemesi", sedangkan rahmah adalah jenis cinta yang lembut, siap berkorban dan siap melindungi kepada yang dicintai. Mawaddah saja kurang menjamin kelangsungan rumah tangga, sebaliknya, rahmah, lama kelamaan menumbuhkan mawaddah.

2. Hubungan antara suami isteri harus atas dasar saling membutuhkan, seperti pakaian dan yang memakainya (hunna libasun lakum wa antum libasun lahunna, Q/2:187). Fungsi pakaian ada tiga, yaitu (a) menutup aurat, (b) melindungi diri dari panas dingin, dan (c) perhiasan. Suami terhadap isteri dan sebaliknya harus menfungsikan diri dalam tiga hal tersebut. Jika isteri mempunyai suatu kekurangan, suami tidak menceriterakan kepada orang lain, begitu juga sebaliknya. Jika isteri sakit, suami segera mencari obat atau membawa ke dokter, begitu juga sebaliknya. Isteri harus selalu tampil membanggakan suami, suami juga harus tampil membanggakan isteri, jangan terbalik di luaran tampil menarik orang banyak, di rumah menyebalkan.

3. Suami isteri dalam bergaul memperhatikan hal-hal yang secara sosial dianggap patut (ma`ruf), tidak asal benar dan hak, Wa`a syiruhunna bil ma 'ruf (Q/4:19). Besarnya mahar, nafkah, cara bergaul dan sebagainya harus memperhatikan nilai-nilai ma ruf. Hal ini terutama harus diperhatikan oleh suami.

4. Suami istri senantiasa menjaga Makanan yang halalan thayyiban. Menurut hadis Nabi, sepotong daging dalam tubuh manusia yang berasal dari makanan haram, cenderung mendorong pada perbuatan yang haram juga (qith `at al lahmi min al haram ahaqqu ila an nar). Semakna dengan makanan, juga rumah, mobil, pakaian dan barang-barang kebutuhan lainnya.

5. Suami istri menjaga aqidah yang benar. Akidah yang keliru atau sesat, misalnya mempercayai kekuatan dukun, majig dan sebangsanya. Bimbingan dukun dan sebangsanya bukan saja membuat langkah hidup tidak rasional, tetapi juga bisa menyesatkan pada bencana yang fatal.

\footnotetext{
${ }^{26}$ Sulaiman Rasjid.Fiqih Islam. Bandung. Sinar Baru Algesinda.1994, 37

27 http:/ /agussyafii.blogspot.com/2009/02/5-konsep-membina-keluargabahagia.html\#ixzz 1uhJYoTLO
} 


\section{Qawwãm • Volume 13 Nomor 2, Desember 2019}

Cara untuk penanggulangan cerai gugat adalah pendewasaan usia pernikahan, karena kalau usia menikah terlalu muda menyebabkan emosi yang masih labil sehingga sering terjadi pertengkaran, perselisihan dan lain sebagainya. Peningkatan pengetahuan calon pasangan suami istri tentang bagaimana membina keluarga yang sakinah, mawaddah dan warahmah, mengerti akan hak dan kewajibannya sebagai suami ataupun sebagai istri sehingga dalam kehidupan keluarga ada rasa saling menghormati, menghargai, menyayangi dan mengasihi. ${ }^{28}$ Untuk memupuk keharmonian hidup berumahtangga, setiap suami isteri hendaklah mematuhi dasar-dasar hukum yang digariskan oleh Islam agar terhindarlah perkaraperkara yang tidak diingini. Islam telah mengingatkan bahawa isteri adalah amanah daripada Allah dan hendaklah dijaga dengan sebaik-baiknya. Bagi pihak isteri pula, Allah telah menegaskan bahawa mereka wajib mentaati suami mereka pada jalan Allah dan haram bau Syurga sekiranya mereka menderhaka terhadap suami selagi si suami patuh dan taat kepada landasan hukum Islam.

Hubungan yang baik antara anak dan ibu bapak akan membawa ke arah keluarga yang bahagia. Islam telah memberikan perhatian yang penting ke atas dua pihak berkenaan. Agama mewajibkan anak-anak mentaati kedua orang tuanya. Sabda Rasulullah yang bermaksud: "Syurga di bawah tapak kaki ibu". Anak-anak harus menumpahkan kasih sayang kepada kedua ibu bapa sekalipun ibu bapa kafir dan ingkar terhadap Allah, namun mereka berhak mendapat penghormatan daripada anak-anak mereka. Ini kerana daripada mereka berdualah lahirnya anak-anak ke dunia ini. Anak-anak harus mentaati ibu bapa mereka yang beragama Islam dalam urusan hidup yang tidak bertentangan dengan Islam. Islam melarang keras kita mencela atau memarahi mereka dengan bahasa yang kasar. Kita haruslah menasihati mereka dengan baik dan sopan. ${ }^{29}$

\section{KESIMPULAN}

Sakinah, mawaddah dan kasih sayang adalah asas dan tujuan disyariatkannya pernikahan dan pembentukan rumah tangga. Namun kenyataannya banyak terjadi dalam keluarga masalah-masalah yang mendorong seorang istri melakukan gugat cerai dengan berbagai faktor. Faktor penyebab cerai gugat diantaranya adalah tidak ada keharmonisan, masalah ekonomi, tidak ada tanggung jawab dari pihak suami sebagai kepala rumah tangga, gangguan orang ketiga, kawin di bawah umur sehingga mengakibatkan kurangnya kedewasaan dalam berfikir, krisis ahlak termasuk kebiasaan mabuk-mabukan dan judi yang sulit disembuhkan, poligami tidak sehat, cemburu, kawin paksa, kekejaman jasmani, kekejaman mental, di hukum, cacat biologis dan faktor politis. Proses cerai gugat akan berakibat pada pembagian harta bersama (gemenshap) dan hak pengurusan anak (badlonah). Harta bersama dalam hukum Islam tidak ditemukan nash yang secara tegas menyebutkan

28 Syamsuddin Abi Abdillah Muhammad bin Abi Bakr. 1980. A'laam al-Muwaqqi’iin 'an Rabb al-'Aalamiin. Cairo: Maktabah Al-Kulliyaat Al-Azhar, jilid. 1, hal. 202. Lihat juga Ibrahim Hoesen, Fikih Perbandingan dalam Masalah Nikah, Thalaq, Rujuk dan Hukum Kewarisan. Jakarta: Balai Penerbitan dan Perpustakaan Islam Yayasan Ihya Ulumuddin Indonesia, 1971, 4.

29 Sobri Mersi Al-paqi, Solusi Problematika Rumah Tangga Modern (Surabaya: Pustaka Yasir) 2011, hal 43. 
hukum harta bersama baik dalam al-Qur'an maupun hadist. Karenanya hal ini merupakan ranah ijtihad bagi ulama yang memiliki kapasitas untuk melakukan ijtihad atau yang dikenal dengan istilah mujtahid. Sedangkan pengurusan anak atau dikenal dengan sebutan badlonah, hukum Islam menyebutkan bahwa apabila terjadi perceraian antara suami dan isteri, maka isterilah yang berhak mengasuh mendidik dan memelihara anak-anaknya selama anak-nya belum mumayyiz:

\section{DAFTAR PUSTAKA}

Amir, Syarifuddin. Hukum Perkawinan Islam di Indoneia antara Fiqh Munakahat dan Undang-undang Perkawinan (Jakarta: Prenada Media. 2007).

Anwar, Syamsul, "Epistemologi Hukum Islam dalam al-Mustashfa min 'Ilm alUshul Karya al-Ghazali (450-505/1058-1111)", Disertasi (Yogyakarta: Program Pascasarjana IAIN Sunan Kalijaga, 2000).

Aripurnami, Sita. Perempuan dan Pemberdayaan (Program Studi kajian Wanita UI. Jakarta, 1997).

As'ad, Abdul Muhaimin. Risalah Nikah (Surabaya: Bintang Terong.1993).

Bakr, Syamsuddin Abi Abdillah Muhammad bin Abi. A'laam al-Muwaqqi'iin 'an Rabb al-'Aalamiin (Cairo: Maktabah Al-Kulliyaat Al-Azhar, 1980).

Basâm, Syeikh Abdullah bin Abdurrahman a-. Taudhih al-Ahkâm Min Bulugh alMarâm (Maktabah al-Asadi, Makkah 5/468)

Buku, Tim Penyusun. Analisis Faktor Penyebab Terjadinya Perceraian Jakarta, Ditbinbanpera Depag RI, 1990).

Engginer, Asghar ali. Pembebasan prempuan, terjemahan Agus nuryanto (Yogyakarta:Lkis,2003).

Faqi, Sobri Mersi Al. Solusi Problematika Modern (Surabaya: Pustaka Yasir, 2011), 29.

Handiyanto, Budi. Perkawinan Beda Agama (Yogyakarta. Chaerul Bayan.2003).

Hoesen, Ibrahim. Fikih Perbandingan dalam Masalah Nikah, Thalaq, Rujuk dan Hukum Kewarisan (Jakarta: Balai Penerbitan dan Perpustakaan Islam Yayasan Ihya Ulumuddin Indonesia, 1971).

Jabiri, Abeed Al. Bunyah al-'Aql al-'Arabi: Dirasah Tabliliyyah al-Naqdiyyah li al-Nuzhum al-Ma'rifah fi al-Tsaqafah al-Islamiyyah (Beirut, Cassablanca: al-Markaz alTsaqafi al-'Arabi, 1993)

Junaedi, Dedi. Bimbingan Perkawinan, Membina Keluarga Sakinah Menurut Al-Qur'an dan as-Sunnah (Jakarta: Akademi Presindo, 2010). 


\section{Qawwãm • Volume 13 Nomor 2, Desember 2019}

Paqi, Sobri Mersi Al. Solusi Problematika Rumah Tangga Modern (Surabaya: Pustaka Yasir, 2011).

Ramulyo, Moh.Idris. Hukum Perkawinan Islam. (Bandung: Mondar Maju.1990).

Rasjid, Sulaiman. Fiqib Islam (Bandung: Sinar Baru Algesinda.1994).

RI, Depag. Bahan Penyuluban Hukum, Undang-undang Perkawinan No.1 tabun 1974. Tentang Perkawinan.

Rofiq, Ahmad. Hukum Islam di Indonesia (Jakarta: PT RajaGrafindo Persada, 1998).

Sabiq, Sayyid. Figh al-Sunnah, jilid 2, (Bairut:Dar al-Fikr 1999).

Syaukani, Muhammad bin Ali al, Tahqiq Mubammad Saalim Haasyim. Nail al-Author Min Ahadits Sayyid al-Akhyaar Syarh Muntaqaa al-Akbbaar (Dar al-Kutub al'Ilmiyah, Bairut 6/260) 